\title{
EVALUATION OF ENVIRONMENTAL CONDITION OF “GJANICA” RIVER MEASURING PHYSICO-CHEMICAL PARAMETERS
}

\author{
Anisa Myrtaj (Rexhepi) ${ }^{1}$ \\ Ilirjan Malollari ${ }^{2}$
}

DOI: https://doi.org/10.31410/ERAZ.2019.365

\begin{abstract}
This paper aims to evaluate the environmental condition of the „Gjanica” river by analyzing different physiochemical parameters. Pollution has been present in this river since the beginning of industrialization and urbanization of the city of Fier, Albania.
\end{abstract}

The main sources of surface water pollution in this country are wastewaters containing organic substances, soluble phosphorous and nitrogen compounds that favor the eutrophication process. A major pollutant of this river has as its source also the oil refinery that discharges untreated waters.

Sampling was carried out at 5 points along the „Gjanica” river, points in which there are significant changes of allowed values of surface water parameters.

Experiments carried out are: $p H$ determination, Redox potential determination, Electrical conductivity determination, dissolved $\mathrm{O}_{2}, \mathrm{BOD}_{5}$, Alkalinity, Chlorides. The assessment of natural waters quality is determined on the physical-chemical parameters comparing with the allowed values in the EU Water Framework Directive.

Keywords: water; wastewater; eutrophication; physiochemical parameter; $p H, B O D$

\section{INTRODUCTION}

Ganica River, $60 \mathrm{~km}$ long, is the main branch of the Seman River and describes it throughout the city of Fier, Albania. The irrational deforestation along the river banks has provoked erosion growth. The problem of Gjanica River pollution has been most aggravated in the last 20 years, with the increase of population and the increase of the activities of different businesses and, this river has already turned into a large collector of sewage. One of the main pollutants of this river is the oil refinery that discharges untreated waters as they are not equipped with a water treatment plant. Oil, which comes from fields of oil wells pollutes and gives the water a smooth surface. Meanwhile, both raw water and industrial waste discharges cause river contamination by organic and inorganic contamination. Historically this river has been also polluted by the chemical fertilizer plant (ammonia, methanol, arsenic, nitrates and phosphates).

Urbanization and industrialization processes bring large amounts of polluted wastewater into the surface waters. The main sources of surface water pollution in our country are urban discharges containing organic substances, soluble phosphorous and nitrogen compounds, which favor the eutrophication process, bacterial and pathogenic viruses, heavy metals, and substances that disrupt the appearance of water and give them a bad smell. 
Urban, industrial and agricultural wastewater discharges into surface waters are a phenomenon that has progressively reduced the quality of rivers, lakes, coastal areas, and the environment in general. In this sense, it is important to assess the quality of surface waters and determine the main pollutants that are discharged into them, with the aim of protecting and / or rehabilitating the environment for integral and sustainable management of water resources.

\section{METHODOLOGY AND RESULTS}

Sampling took place at 5 points along the „Gjanica” river, points where there are significant changes in the allowed values of surface water parameters. The samples were packed in $1.5 \mathrm{~L}$ polyethylene bottles. Sampling was performed on a day in a month and all the samples were taken during one hour. During this time the samples were protected from the atmosphere oxygen, sunlight and stored in the refrigerator at $2-8{ }^{\circ} \mathrm{C}$. The time for conducting the experiments, from the sampling point, was 0-10 days.

Table 1: Sampling points

\begin{tabular}{l|l}
\hline Sampling points & Location \\
\hline Sample 1 (M1) & Near the source \\
Sample 2 (M2) & Shaban Agai bridge (Ballsh) \\
Sample 3 (M3) & Visoka bridge \\
Sample 4 (M4) & On the bridge in the city center \\
Sample 5 (M5) & "Gjanica" effluent stream \\
\hline
\end{tabular}

During the analyzes of waters were performed these measurements:

- Determination of $\mathrm{pH}$,

- Determining the Redox Potential,

- Determination of electrical conductivity,

- $\mathrm{O}_{2}$ dissolved,

- BOD (biological oxygen demand),

- Alkalinity,

- Chloride,

- Determination of solid matter.

The assessment of the quality of natural waters is determined on the basis of physiochemical parameters comparing with the permissible norms laid down in the EU Water Framework Directive.

Table 2. Allowed norms of physical-chemical parameters

\begin{tabular}{l|l}
\hline Physicochemical Parameters & Allowed values \\
\hline Dissolved Oxygen & $>7 \mathrm{mg} / 1$ \\
Temperature & $14-20^{\circ} \mathrm{C}$ \\
$\mathrm{pH}$ & $<8.5$ \\
$\mathrm{BOD}$ & $<3.0 \mathrm{mg} / 1$ \\
$\mathrm{P}-\mathrm{PO}_{4}{ }^{3-}$ & $<0.4 \mathrm{mg} / 1$ \\
$\mathrm{~N}^{-} \mathrm{NO}_{2}$ & $<0.12 \mathrm{mg} / 1$ \\
$\mathrm{~N}-\mathrm{NO}_{3}$ & $<0.8 \mathrm{mg} / 1$ \\
Alkalinity & $100-250 \mathrm{mg} / 1$ \\
Chlorides & $45-155 \mathrm{mg} / 1$ \\
\hline
\end{tabular}




\subsection{Determination of physic - chemical parameters:}

Table 3. Experimental results obtained during the analysis of samples

\begin{tabular}{|c|c|c|c|c|}
\cline { 2 - 5 } \multicolumn{1}{c|}{} & Dissolved $\boldsymbol{O}_{\mathbf{2}}(\boldsymbol{m g} / \boldsymbol{l})$ & $\boldsymbol{O}_{\mathbf{2}} \boldsymbol{\%}$ & $\boldsymbol{B O D}(\boldsymbol{m g} / \boldsymbol{l})$ & $\boldsymbol{p H}$ \\
\hline M1 & 7.5 & 93 & 1.5 & 7.93 \\
\hline M2 & 4.25 & 38 & 3.7 & 7.76 \\
\hline M3 & 7.25 & 79 & 2.4 & 7.82 \\
\hline M4 & 5.35 & 60.3 & 1.2 & 7.67 \\
\hline M5 & 5.25 & 52.1 & 2.7 & 7.59 \\
\hline
\end{tabular}

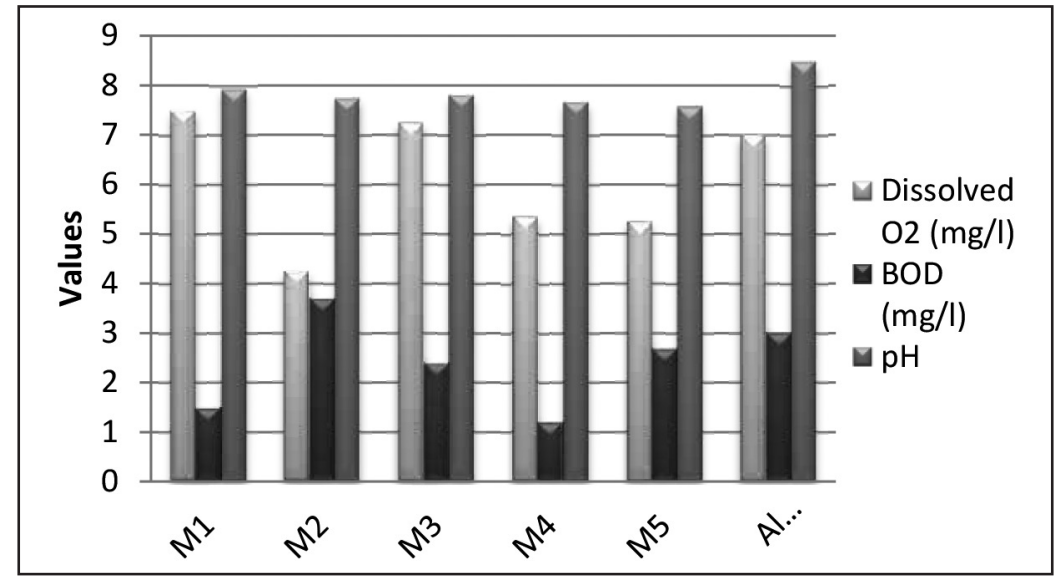

Figure 1. Graphic dependence of three parameters taken from analysis compared to the allowed values

Table 4. Experimental results obtained during the analysis of samples for alkalinity, conductivity, chlorides and redox potential

\begin{tabular}{|c|c|c|c|c|}
\cline { 2 - 5 } \multicolumn{1}{c|}{} & Alkalinity $(\boldsymbol{m g} / \boldsymbol{l})$ & Conductivity $(\boldsymbol{\mu s})$ & Chlorides $(\boldsymbol{m g} / \boldsymbol{l})$ & Redox potential $(\boldsymbol{m} \boldsymbol{v})$ \\
\hline M1 & 225 & 636 & 4.5 & -54 \\
\hline M2 & 245 & 1216 & 274.43 & -53 \\
\hline M3 & 250 & 928 & 73.48 & -47 \\
\hline M4 & 210 & 1027 & 97.97 & -38 \\
\hline M5 & 260 & 1100 & 121.47 & -40 \\
\hline
\end{tabular}

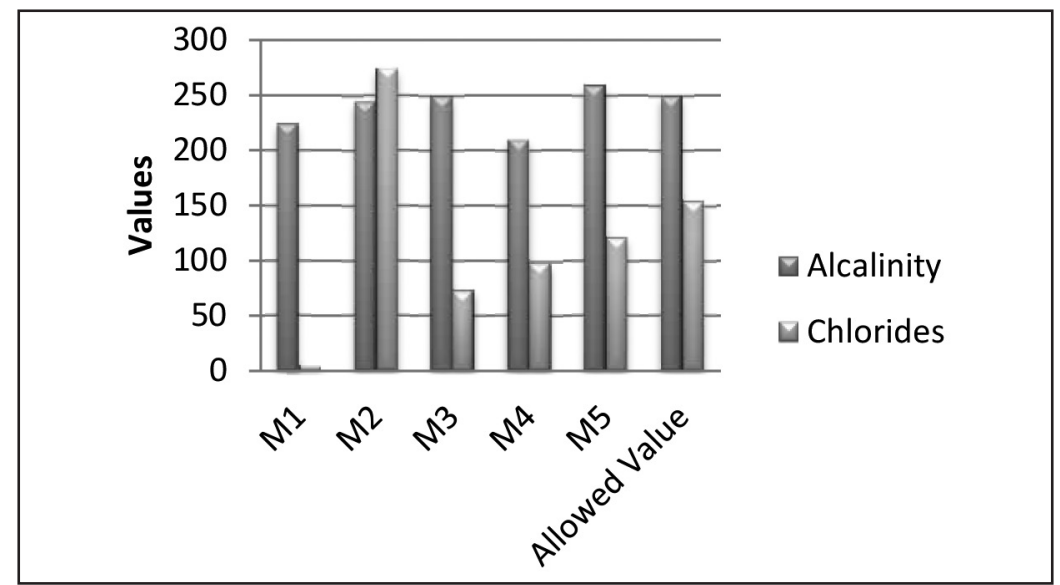

Figure 2. Graphic dependence of alkalinity and chlorides from the allowed values 


\subsection{Determination of nitrates $\mathrm{N}-\mathrm{NO}_{3}{ }^{-}$}

The results of work we have taken from measurements on standards:

Table 5. Presents concentrations for the preparation of standard $\mathrm{N}-\mathrm{NO}_{3}$

\begin{tabular}{|c|c|c|c|c|c|}
\hline & $P b$ & St.1 & St.2 & St. 3 & St.4 \\
\hline $\mathrm{C}_{\mathrm{N}-\mathrm{NO} 3}(\mathrm{mg} / \mathrm{l})$ & 0.0 & 0.1 & 0.2 & 0.5 & 1 \\
\hline $\mathrm{V}_{\mathrm{N}-\mathrm{NO} 3}(\mathrm{ml})$ & 0 & $50 \mu 1$ & $100 \mu 1$ & $250 \mu 1$ & $500 \mu 1$ \\
\hline $\mathrm{V}_{\mathrm{H} 2 \mathrm{O}}(\mathrm{ml})$ & 50 & 50 & 50 & 50 & 50 \\
\hline $\mathbf{A}_{220 \mathrm{~nm}}$ & 0.0 & 0.358 & 0.707 & 1.476 & 2.998 \\
\hline $\mathbf{A}_{275 \mathrm{~nm}}$ & 0.0 & 0.002 & 0.003 & 0.007 & 0.000 \\
\hline
\end{tabular}

From the results obtained from the treatment of the samples, we calculate the absorption for nitrate ions according to the formula:

$$
\mathrm{A}_{\mathrm{NO} 3}=\mathrm{A}_{220}-\left(2_{*} \mathrm{~A}_{275}\right)
$$

Calculated values are shown in the following table:

Table 6. Experimental results obtained during the $\mathrm{N}_{-} \mathrm{NO}_{3}$ absorption difference and organic matter of water samples of the „Gjanica” river

\begin{tabular}{|c|c|c|c|c|c|}
\cline { 2 - 6 } \multicolumn{1}{c|}{} & $\boldsymbol{P b}$ & $\boldsymbol{S t . 1}$ & $\boldsymbol{S t . 2}$ & $\boldsymbol{S t . 3}$ & $\boldsymbol{S t . 4}$ \\
\hline $\mathbf{C}_{\mathrm{N}-\mathrm{NO3}}(\mathbf{m g} / \mathbf{I})$ & 0.0 & 0.1 & 0.2 & 0.5 & 1 \\
\hline $\mathbf{A}_{\mathrm{NO3}}$ & 0 & 0.356 & 0.704 & 1.469 & 2.998 \\
\hline
\end{tabular}

Now we build the calibration curve for the above data:

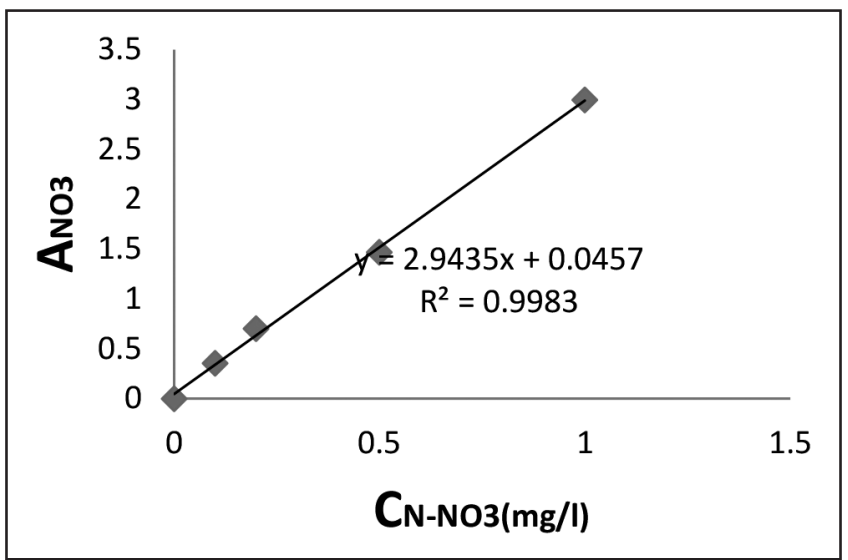

Figure 3. Calibration curve of nitrate ion standards $\mathrm{N}-\mathrm{NO}_{3}$

Observing the calibration curve, we see that the linearity dependence is according to the formula:

$$
\begin{aligned}
& \mathrm{Y}=2.9433 \mathrm{x}+0.0456 \text { when: } \mathrm{y} \rightarrow \text { absorbance value } \\
& \mathrm{A}_{\mathrm{x}}=2.9433 \mathrm{C}_{\mathrm{x}}+0.0456 \mathrm{x} \rightarrow \text { concentration values }
\end{aligned}
$$

Calculate the concentration of nitrate ions for the samples taken in the study:

$$
C_{x}=A_{x}-0.0456 / 2.9433
$$


Table 7. The experimental results obtained during the analysis of $\mathrm{N}^{-\mathrm{NO}_{3}}$ ions

\begin{tabular}{|c|c|c|c|c|c|}
\hline $\boldsymbol{A x}(\mathbf{n m})$ & $\mathbf{0 . 2 2 8}$ & $\mathbf{0 . 1 1 0}$ & $\mathbf{0 . 1 3 9}$ & $\mathbf{0 . 7 6 6}$ & $\mathbf{0 . 6 2 0}$ \\
\hline $\mathbf{C x}(\mathbf{m g} / \mathbf{l})$ & 0.08 & 0.021 & 0.031 & 0.24 & 0.19 \\
\hline
\end{tabular}

\subsection{Determination of nitrite $\mathrm{N}_{-} \mathrm{NO}_{2}^{-}$}

Table 8. Concentrations for the preparation of standard solutions of $\mathrm{N}^{-\mathrm{NO}_{2}{ }^{-}}$

\begin{tabular}{|c|c|c|c|c|c|}
\cline { 2 - 6 } \multicolumn{1}{c|}{} & $\boldsymbol{P b}$ & St.1 & St.2 & St.3 & St.4 \\
\hline $\mathbf{C}_{\text {N-NO2}}(\mathbf{m g} / \mathbf{l})$ & 0.0 & 0.01 & 0.02 & 0.04 & 0.08 \\
\hline $\mathbf{V}(\mathbf{m l})$ of st. 10 mg/l & 0 & $50 \mu l$ & $100 \mu 1$ & $200 \mu 1$ & $400 \mu 1$ \\
\hline $\mathbf{V}_{\mathbf{H 2 O}}(\mathbf{m l})$ & 50 & 50 & 50 & 50 & 50 \\
\hline $\mathbf{A}_{\mathbf{5 4 3 n m}}$ & 0 & 0.022 & 0.057 & 0.129 & 0.260 \\
\hline
\end{tabular}

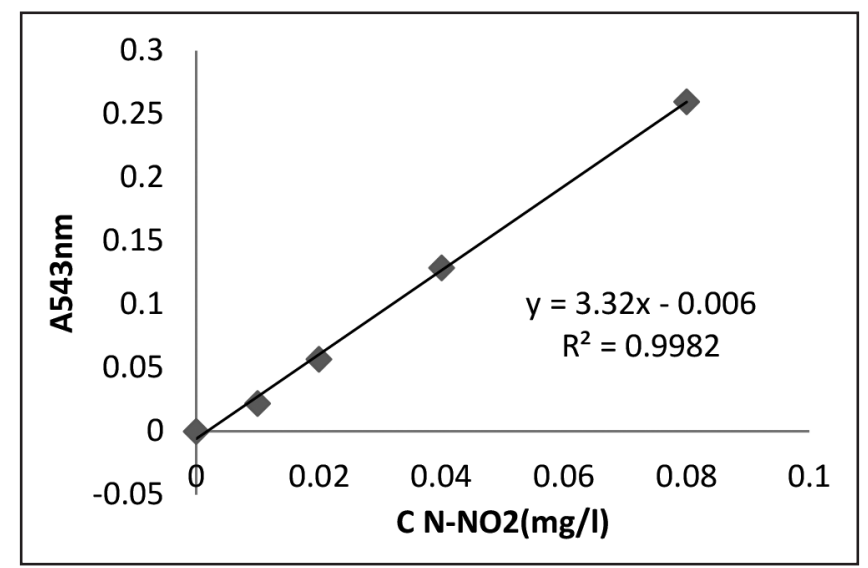

Figure 4. Calibration curve of nitrite ion standards $\mathrm{N}_{-} \mathrm{NO}_{2}$

From the calibration curve we find concentrations of nitrite ions $\mathrm{N}-\mathrm{NO}_{2}:$

$\mathrm{y}=3.32 \mathrm{x}-0.006 \quad$ when: $\mathrm{y} \rightarrow$ absorbance value

$A x=3.32 C x-0.006 \quad x \rightarrow$ concentration value

$\mathrm{Cx}=\mathrm{Ax}+0.006 / 3.32$

Table 9. The experimental results obtained during the analysis of $\mathrm{N}-\mathrm{NO}_{2}$ ions

\begin{tabular}{|c|c|c|c|c|c|}
\hline $\boldsymbol{A x}(\mathbf{n m})$ & $\mathbf{0 . 0 0 2}$ & $\mathbf{0 . 0 1 5}$ & $\mathbf{0 . 0 1 1}$ & $\mathbf{0 . 0 1}$ & $\mathbf{0 . 0 1}$ \\
\hline $\mathbf{C x}(\mathbf{m g} / \mathbf{l})$ & 0.002 & 0.006 & 0.005 & 0.0048 & 0.0048 \\
\hline
\end{tabular}

\subsection{Determination of phosphate ions $\mathrm{P}_{-} \mathrm{PO}_{4}{ }^{3-}$}

Table 10. Concentrations for the preparation of standard solutions $\mathrm{P}_{-} \mathrm{PO}_{4}{ }^{3-}$

\begin{tabular}{|c|c|c|c|c|c|}
\cline { 2 - 6 } \multicolumn{1}{c|}{} & $\boldsymbol{P b}$ & St.1 & St.2 & St.3 & St.4 \\
\hline $\mathbf{C ~ i ~ P O} \mathbf{4}^{3--}-\mathbf{P}$ & 0.0 & 0.025 & 0.05 & 0.1 & 0.2 \\
\hline $\begin{array}{c}\mathbf{V}(\mathbf{m l}) \mathbf{I} \text { work st } \\
\mathbf{1 0}(\mathbf{m g} / \mathbf{l})\end{array}$ & 0 & $125 \mu 1$ & $250 \mu 1$ & $500 \mu 1$ & $1000 \mu 1$ \\
\hline $\mathbf{V}_{\text {H20 }}(\mathbf{m l})$ & 50 & 50 & 50 & 50 & 50 \\
\hline $\mathbf{A}_{880 \mathrm{~nm}}$ & 0 & 0.014 & 0.024 & 0.049 & 0.0987 \\
\hline
\end{tabular}




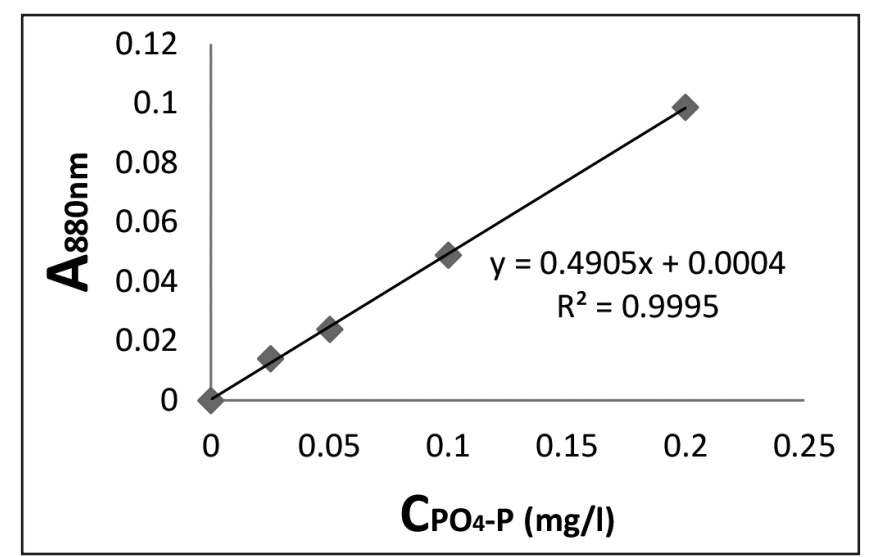

Figure 5. Calibration curve of phosphate ions $\mathrm{P}_{-} \mathrm{PO}_{4}{ }^{3-}$

$\mathrm{y}=0.4905 \mathrm{x}+0.0004 \quad$ when: $\mathrm{y} \rightarrow$ absorbance value

$\mathrm{Ax}=0.4905 \mathrm{Cx}+0.0004 \mathrm{x} \rightarrow$ concentration value

$\mathrm{Cx}=\mathrm{Ax}-0.0004 / 0.4905$

Table 11. The experimental results obtained during the analysis of $\mathrm{P}_{-} \mathrm{PO}_{4}{ }^{3-}$ ions

\begin{tabular}{|c|c|c|c|c|c|}
\hline $\boldsymbol{A x}(\mathbf{n m})$ & $\mathbf{1 . 6 8 8}$ & $\mathbf{1 . 6 9 8}$ & $\mathbf{1 . 5 5 5}$ & $\mathbf{1 . 8 1 3}$ & $\mathbf{1 . 7 6 6}$ \\
\hline $\mathbf{C x}(\mathbf{m g} / \mathbf{l})$ & 3.44 & 3.46 & 3.16 & 3.69 & 3.59 \\
\hline
\end{tabular}

\section{CONCLUSION}

From this study we carried out that the samples taken over the river „Gjanica” are generally polluted throughout the river bed, but the largest pollution is exactly the point that is directly affected by untreated waters discharge. Also, we can't leave behind the other part of the river which is polluted by the sewage that drains on it, and other industrial discharges that have their activities near the river bed.

To conclude, we suggest the construction of a wastewater plants for minimizing the pollution of the Gjanica River, especially of the Ballsh Plant, and the immediate placement of filters for all industries that discharge their discharge into this river.

\section{REFERENCES}

[1] Bode A., P. Zoga "Probleme te impaktit ambiental ne grykederdhjen e Semanit ne detin Adriatik", Buletini Nafta Shqiptare Volumi 163, Nr3. 2009

[2] Cullaj A., Kimia e Mjedisit, Shblu, Tiranë, 2005

[3] International Review for Environmental Strategies, Volume 4, Number 2, 2003, ISSN 1345759

[4] Tashko A. Gjeokimia. Ligjësi dhe zbatime, Shblu, Tiranë, 2006

[5] USEPA Water Quality Criteria for Nitrogen and Phosphorus Pollution, 2004

[6] Cullaj A., et al, Environmental state of some rivers of Albania Adriatik lowland, Tiranë 2005 
[7] Ecological Society of America. 1998 Celia, M.A., Herrera, I., Bouloutas, E.T., Kindred, J.S. (1989), „A new numerical approach for the advective-diffusive transport equation”, Numerical Methods for Partial Differential

[8] Ellen Wohl1, Compromised Rivers: Understanding Historical Human Impacts on Rivers in the Context of Restoration,

[9] Faeth, P. Fertile Ground: Nutrient Trading's Potential to Cost-Effectively Improve Water Quality. Washington, DC: World Resources Institute. 2000

[10] Metcalf \& Eddy. Wastewater Engineering: Treatment, Disposal, Reuse. New York: Mc Grow- Hill, 1991 